\title{
What Is the Developmentalist Challenge?
}

\author{
Paul E. Griffiths; Robin D. Knight
}

Philosophy of Science, Vol. 65, No. 2. (Jun., 1998), pp. 253-258.

Stable URL:

http://links.jstor.org/sici?sici=0031-8248\%28199806\%2965\%3A2\%3C253\%3AWITDC\%3E2.0.CO\%3B2-U

Philosophy of Science is currently published by The University of Chicago Press.

Your use of the JSTOR archive indicates your acceptance of JSTOR's Terms and Conditions of Use, available at

http://www.jstor.org/about/terms.html. JSTOR's Terms and Conditions of Use provides, in part, that unless you have obtained prior permission, you may not download an entire issue of a journal or multiple copies of articles, and you may use content in the JSTOR archive only for your personal, non-commercial use.

Please contact the publisher regarding any further use of this work. Publisher contact information may be obtained at http://www.jstor.org/journals/ucpress.html.

Each copy of any part of a JSTOR transmission must contain the same copyright notice that appears on the screen or printed page of such transmission.

The JSTOR Archive is a trusted digital repository providing for long-term preservation and access to leading academic journals and scholarly literature from around the world. The Archive is supported by libraries, scholarly societies, publishers, and foundations. It is an initiative of JSTOR, a not-for-profit organization with a mission to help the scholarly community take advantage of advances in technology. For more information regarding JSTOR, please contact support@ jstor.org. 


\title{
What is the Developmentalist Challenge?*
}

\author{
Paul E. Griffiths ${ }^{\dagger}$ \\ Unit for History and Philosophy of Science, University of Sydney \\ Robin D. Knight \\ Department of Ecology and Evolutionary Biology, Princeton University
}

Kenneth C. Schaffner's paper is an important contribution to the literature on behavioral genetics and on genetics in general. Schaffner has a long record of injecting real molecular biology into philosophical discussions of genetics. His treatments of the reduction of Mendelian to molecular genetics (Schaffner 1967, 1969) first drew philosophical attention to the problems of detail that have fuelled both anti-reductionism (Hull 1974, Kitcher 1984) and more sophisticated models of theory reduction (Sarkar 1992, Schaffner 1993). An injection of molecular detail into discussions of genetics is particularly necessary at the present time, when so many philosophers seem happy to discuss the philosophical and ethical implications of molecular biology using gene concepts derived from evolutionary biology (i.e., the 'evolutionary gene concept' of G.C Williams (Williams 1966, Dawkins 1982)). Schaffner has long advocated the view that the philosophy of biology should be more than the philosophy of evolution. This paper shows how radically a picture of gene action derived from molecular biology undercuts the popular picture associated with a more evolutionary view of genes as units of heredity or as 'difference-makers' mediated by the 'black box' of development (Sterelny and Kitcher 1988).

We are advocates of the developmental systems or developmental constructionist 'challenge' to conventional ideas about genetics that Schaffner describes in this paper. Many claims about genes that pass for truisms in the broader intellectual community are unsustainable. DNA does not contain a program for development. Genes are not 'selfreplicating' except in the misleading sense in which membranes, meth-

*Received September 1997.

†Send requests for reprints to Prof. Griffiths, Unit for History and Philosophy of Science, University of Sydney, Carslaw Bldg. F07, Sydney, NSW 2006, Australia; e-mail: pgriffiths@scifac.edu.au.

Philosophy of Science, 65 (June 1998) pp. 253-258. 0031-8248/98/6502-0003\$2.00

Copyright 1998 by the Philosophy of Science Association. All rights reserved. 
ylation patterns and cytoplasmic gradients are all 'self-replicating'. Genes are not the sole or main units of selection. In this commentary, we examine Section 6 of Schaffner's paper, in which he asks how well C. elegans bears out five developmentalist 'themes'. We ask how accurately these themes represents the developmentalist position. With one exception Schaffner's themes are well-chosen, but some clarification of them will be useful.

1. Parity is the idea that genes and other material causes are on a par. The 'strawman' parody of developmentalism says that all developmental causes are of equal importance. The real developmentalist position is that the empirical differences between the role of DNA and that of cytoplasmic gradients or host-imprinting events do not justify the metaphysical distinctions currently built upon them. Nucleic acid sequences and phospholipid membranes both have distinctive and essential roles in the chemistry of life and in both cases there seems no realistic substitute for them. But the facts of development do not justify assigning DNA the role of information and control while inherited membrane templates get the role of 'material support' for reading DNA. The facts of evolution do not justify a special role for DNA sequences as 'replicators' whilst membranes are lumped together with everything from methyl groups to human culture as 'interactors'.

Schaffner mentions three grounds for denying parity. We are not sure that he means to endorse the first: that genes are different because they are all that organisms inherit. This idea has by now surely ceased to be orthodox. Basal bodies and microtubule organizing centers, DNA methylation patterns, membranes and organelles are all inherited (Jablonka and Lamb 1995, Jablonka and Szathmáry 1995, Moss 1992). Changes in these epigenetic elements cause heritable variation in the cellular phenotype. They constitute additional 'epigenetic inheritance systems' (Jablonka and Szathmáry 1995). Develomentalism extends inheritance still further. Some castes of the aphid Colophina arma require a growth spurt as part of their life-cycle. These and only these castes inherit the necessary endosymbionts (Morgan and Baumann 1994). The morphology of queens and the colony structure of the fire ant Solenposis invicta differ radically between genetically similar lineages of the species because of stably reproduced pheremonal nest cultures (Keller and Ross 1993). A principled definition of inheritance must include whatever is present in each generation and helps reconstruct the life-cycle (Griffiths and Gray 1994).

Schaffner mentions the claim that there is a one-way flow of information from DNA to protein as a ground for denying parity. The developmentalist question is how much we should make of two empir- 
ical facts: the triplet code is an important part of how proteins are made, and in organisms with segregated germ-lines somatic mutations are not inherited. These facts themselves should not be oversold. DNA sequence alone does not determine the final protein sequence and most organisms do not have a segregated germ line. The broader idea that DNA encodes developmental information simply cannot be raised above the level of a metaphor, as is very thoroughly demonstrated in a recent paper by Sahotra Sarkar (Sarkar 1996).

Schaffner's conclusion concerning parity is that genes are causally on a par with other factors but epistemically and heuristically first amongst equals. They are a uniquely powerful tool for exploring development (although this may simply reflect the fact that genes are the element that has been most thoroughly investigated to date). Schaffner cites with approval Gunther Stent's idea that we should reject the ideology of genetic determinism while embracing the instrumental primacy of genetics. We suggest that the molecular revolution has now progressed beyond the instrumental primacy of the gene. The claim that the 'eyeless' gene in Drosophila is a 'master control gene' need not be rebutted by vague talk about the necessity of other elements of the developmental matrix. It can be shown to be unhelpful by looking at the molecular detail of the context in which this sequence apparently assumes such significance (Burian 1997). The continuing impression that molecular biology is all about genes is partly an illusion: 'gene' has become an informal, contextual term denoting different kinds of molecular mechanism in different disciplinary contexts (NeumannHeld 1997).

2. Non-preformationism is the denial that there are pre-formed blueprints or representations of traits in DNA. Genes do not contain what Schaffner delightfully labels 'traitunculi'. Schaffner argues that $C$. elegans researchers all have the alternative, properly epigenetic, perspective on gene action. But this does not mean that non-preformationism is flogging a dead horse. First, if the idea of genetic control is granted heuristic value by molecular biologists, as Schaffner suggests, it will inevitably turn into 'hard fact' in popular science. Second, the idea that genes specify traits is alive and well in evolutionary thought. Gene selectionist evolutionary explanations typically consist of a selection scenario for a phenotypic trait plus the claim that it is really the 'genes for' the trait that are being selected. The 'gene for' locution drawn from medical genetics is thus brought together with the evolutionary gene concept of Williams and Dawkins. This gives the impression that gene selectionism is discussing real genes, not the arbitary stretches of DNA with no constant effect found in the official definition of the evolution- 
ary gene concept. In fact, the 'gene for' concept and the evolutionary gene concept entirely fail to connect at the molecular level. When gene action is epigenetic in the way Schaffner describes, then the differences in DNA sequence that account for variance in a phenotypic trait (the 'genes for' the trait) will typically change during a selection process: "whether a particular gene is perceived to be a major gene, a minor gene or even a neutral gene depends entirely on the genetic background in which it occurs, and this apparent attribute of a gene can change rapidly in the course of selection on the phenotype" (Nijhout and Paulsen 1997, 401-403). At the very least, the idea that the 'genes for' traits are constant difference-makers that underly trait differences during selection has done a great deal to popularize gene selectionism. In a forthcoming paper we argue that this fallacy is actually essential to gene selectionisms' apparent ability to explain phenotypic adaptation (Knight and Griffiths forthcoming).

The final addition to this mix of neo-preformationist confusions is that the 'gene for' locution is normally explained using atypical, pathological cases in which the complexities of the gene-phenotype relation really can be ignored. 'Genes for' disease phenotypes involve a major defect in an evolved gene whose normal role involves connections to many other genes, either by direct protein/protein interaction or downstream in vital pathways. It seems that the Odr-7 gene that Schaffner cites as an exception to the epigenetic action of genes in C. elegans works in this way. Such pathological genes impair function under almost any background conditions. However, as Schaffner notes, explanation of normal function in terms of the normal forms of such genes is the weakest form of explanation: they are 'genes for' traits only in the sense that they are one necessary condition for those traits to develop.

3. Contextualism is the view that "genes have little meaning ... per se, only in context with other genes and in an environment that is cellular, extracellular and extraorganismic" (Schaffner this issue, 000). Schaffner accepts this view and argues that the $C$. elegans research community accepts it. In a recent paper Eva Neumann-Held argues that contextualism can provide a gene concept adequate to the complexities of current molecular biology and to that holy grail of gene concepts, the reduction of the Mendelian gene. She suggests that the real molecular correlate of a Mendelian gene is not a classical molecular gene (a reading sequence) but such a sequence plus the whole complex of resources which surround it when it occurs in certain contexts in a lineage of organisms. It is this whole contextualized system that recurs from one generation to the next and which accounts for the pattern of inheritance 
at the phenotypic level that the Mendelian gene was introduced to explain (Neumann-Held 1997).

4. Indivisibility is described by Schaffner as the view that individual genetic and environmental causes cannot be identified by seperable effects on the phenotype. He questions whether the epigenetic nature of gene action justifies such a claim, and argues that in practice the different causal contributions of causal factors can be teased apart. Development, he says, is not an emergent phenomenon in any strong sense. Developmentalism has no quarrel with any of this. In our view, and what we think is the view of leading developmentalist figures like Susan Oyama (Oyama 1985), the point of indivisibility is that the effects of all causal factors are context dependent. The 'gene for' locution uses a context-sensitive effect to label a sequence that can occur in contexts where that effect no longer applies. Richard Lewontin's seminal paper, "The analysis of variance and the analysis of causes" (1974), makes the same point for quantitative, as opposed to qualitative, claims about gene effects. Heritability analyses cannot be used to measure 'how genetic' a trait is because the measure arrived at depends on the particular environmental context. Indivisibility is an important theme, because while specific factors have specific effects, they have them only in a specific context of other factors.

5. Unpredictability is the claim that traits are strongly emergent because they cannot be predicted from total information about genes and environment. Schaffner denies unpredictability, and argues that irreducible appeals to 'developmental noise' (sheer stochasticity) should be viewed with suspicion. We are entirely in agreement with Schaffer on these issues: "the entire set of developmental resources, plus its spatiotemporal structure, may be said to contain information about developmental outcomes in the unproblematic, mathematical sense of systematic dependence" (Griffiths and Gray 1994, 282). We see the issue of whether development is noisy as orthogonal to the question of whether it is genetically programmed. Developmentalism is not concerned with whether we can 'compute the embryo', but with what we can compute it from. In fact, one developmentalist theme Schaffner does not mention is materialism. The ideas of 'programming' and 'genetic information' have consistently been condemned as pseudo-explanations which attempt to short-circuit the need for real developmental biology (Lickliter and Berry 1990). The unproblematic, materialistic sense in which development is an 'emergent' property of biological complexity advocated by Schaffner and by Bechtel and Richardson 
(Bechtel and Richardson 1993) is the only sense developmentalism is interested in.

In conclusion, let us just note that Schaffner's conclusion, that development is an orchestra with no conductor, expresses the key thesis of developmentalism very nicely. Schaffner is a developmentalist.

\section{REFERENCES}

Bechtel, W. and R. Richardson (1993), Discovering Complexity. Princeton: Princeton University Press.

Burian, R. M. (1997), “On conflicts between genetic and developmental viewpoints-and their attempted resolution in molecular biology", in M. L. Dalla Chiara et al. (eds.), Structures and Norms in Science. Dordrecht: Kluwer, pp. 243-264.

Dawkins, R. (1982), The Extended Phenotype. Oxford: Freeman.

Griffiths, P. E. and R. D. Gray (1994), "Developmental Systems and Evolutionary Explanation", Journal of Philosophy XCI (6): 277-304.

Hull, D. (1974), Philosophy of Biological Science. New Jersey: Prentice-Hall Inc.

Jablonka, E. and M. J. Lamb (1995), Epigenetic Inheritance and Evolution: The Lamarkian Dimension. Oxford, New York, Tokyo: Oxford University Press.

Jablonka, E. and E. Szathmáry (1995), "The evolution of information storage and heredity", Trends in Ecology and Evolution 10 (5): 206-211.

Keller, L. and K. G. Ross (1993), "Phenotypic plasticity and 'cultural transmission' of alternative social organisations in the fire ant solenopsis invicta", Behavioural Ecology and Sociobiology 33: 121-129.

Kitcher, P. (1984), "1953 and all that: A Tale of Two Sciences ", Philosophical Review 93: 335-373.

Knight, R. D. and P. E. Griffiths (forthcoming), "Selfish Genes: The Eunuchs of Selection".

Lewontin, R. (1974), "The analysis of variance \& the analysis of causes", American Journal of Human Genetics 26: 400-411.

Lickliter, R. and T. Berry (1990), "The phylogeny fallacy”, Developmental Review 10: 348-364.

Morgan, N. and P. Baumann (1994), "Phylogenetics of cytoplasmically inherited microorganisms of arthropods", Trends in Ecology and Evolution 9: 15-20.

Moss, L. (1992), "A kernel of truth? On the reality of the genetic program", Philosophy of Science Association Proceedings 1992 Vol.1: 335-348.

Neumann-Held, E. M. (1997), "The Gene is Dead-Long Live the Gene: Conceptualising the Gene the Constructionist Way", in P. Koslowski (ed.), Developmental Systems, Competition and Cooperation in Sociobiology and Economics. Berlin: Springer-Verlag, 000-000.

Nijhout, H. F. and S. M. Paulsen (1997), "Developmental models and polygenic characters", American Naturalist 149: 394405.

Oyama, S. (1985), The Ontogeny of Information. Cambridge: Cambridge University Press.

Sarkar, S. (1992), "Models of reduction and categories of reductionism", Synthese 91: 167-194.

- (1996), "Biological information: A sceptical look at some central dogmas of molecular biology", in S. Sarkar (ed.), The Philosophy and History of Molecular Biology: New Perspectives. Dordrecht: Kluwer Academic Publishers, pp. 187-232.

Schaffner, K. (1967), “Approaches to Reduction”, Philosophy of Science 34: 137-147.

- (1969), "The Watson-Crick model and reductionism", British Journal for the Philosophy of Science 20: 325-348.

- (1993), Discovery and Explanation in Biology and Medicine. Chicago and London: University of Chicago Press.

Sterelny, K. and P. Kitcher (1988), "The return of the gene", Journal of Philosophy 85 (7): 339-361.

Williams, G. C. (1966), Adaptation \& Natural Selection. Princeton: Princeton University Press. 